\title{
Occurrence of Citrus Greening Disease in the Southern Islands of Japan*
}

\author{
Tsunekuni MiyakaWA** and Kazunobu Tsuno***
}

Key words : citrus greening, bacterium-like organism, Ryukyu islands.

Citrus greening disease is widely distributed in the citrus growing area of South East Asian countries, southern China mainland and Taiwan, and is considered to be the most injurious citrus diseases ${ }^{1-4)}$.

The southernmost area of Okinawa Prefecture, the Nansei (Ryukyu) islands, are located $200 \mathrm{~km}$ east of Taiwan (Fig. 1). Although there was no report of citrus greening in this area ${ }^{5}$, there has been some likelihood of its occurrence because the insect vector, Diaphorina citri Kuwayama, is present ${ }^{6}$.

In March, 1988, a survey trip was made to Ishigaki and Iriomote islands (Fig. 1), and suspect trees from citrus orchards in both islands were inspected and sampled for greening disease. Six places were visited in Ishigaki and three in Iriomote islands in this survey. Some citrus trees showed abnormalities resembling nutritional disorders, including chlorosis and yellowing of leaves and a poor tree vigor. Fruit symptoms could not be observed because fruit was not present at that time.

Bud samples were collected from 16 suspect trees, including kumquat (Fortunella sp.), satsuma (Citrus unshiu), and a local variety, Shiikuwasha (C. depressa), in nine places and were taken to the facilities of Minami Kyushu University.

The samples were indexed by bud inoculation into Ponkan (C. reticulata) seedlings trained as indicator plants in greenhouse for 9 to 12 months. The seedlings were bud-inoculated with at least 5 or more buds per plant and cut back to force new growth. The inoculated seedlings were grown for symptom observation in a phytotron (26-30 C) and a greenhouse (20-30 C). About two to three months after inoculation, the Ponkan seedlings inoculated from two sources of Shiikuwasha trees revealed irregular chlorosis and yellowing of the leaves, typical of greening disease (huanglongbin or likubin) in Taiwan ${ }^{1,7}$ (Fig. 2). Infectivity of these inoculum sources was repeatedly confirmed by subinoculation to additional Ponkan seedlings.

Leaves of the inoculated Ponkan seedlings showing greening symptoms were examined by electron microscopy. For thin sectioning, pieces of leaves showing chlorosis were trimmed $1 \mathrm{~mm}^{2}$ and fixed with $2.5 \%$ glutaraldehyde at $4 \mathrm{C}$ overnight, and $2 \% \mathrm{OsO}_{4}$ in $0.1 \mathrm{M}$ phosphate buffer, $\mathrm{pH} 7.4$, for $2 \mathrm{hr}$ at room temperature. After dehydration with a graded series of ethanol followed by transferring to QY-1 ( $n$-butyl glycidyl ether), they were embedded in

* This work was supported in part by FFTC/ASPAC.

** College of Horticulture, Minami Kyushu University, Takanabe, Miyazaki 884, Japan 南九州 大学園芸学部

*** Faculty of Agriculture, Kyushu University, Fukuoka 812, Japan九州大学農学部

1) Matsumoto, T. and Su, H.J. (1966). J. Agr. Assoc. China, New Ser. No. 56: 1-12. 2) Zhao, X.Y. (1981). Proc. Int. Soc. Citriculture I. 466-469. 3) Martinez, A.L. and Wallace, J.M. (1969). Proc. 1st Citrus Symp. 3: 1427-1431. 4) Bhavakul, K., Intavimolsri, S., Vichitrananda, S., Kratureuk, C. and Promintara, M. (1981). Proc. Int. Soc. Citriculture I. 464-466. 5) Miyakawa, T., Tanaka, H. and Matsui, C. (1974). Proc. 6th Conf. IOCV, Univ. Calif. Div. Agric. Sci., Berkeley pp. 40-42. 6) Miyatake, Y. (1965). Kontyu 33:171-189. 7) Miyakawa, T. (1981). Ann. Phytopath. Soc. Japan 46: 224-230. 


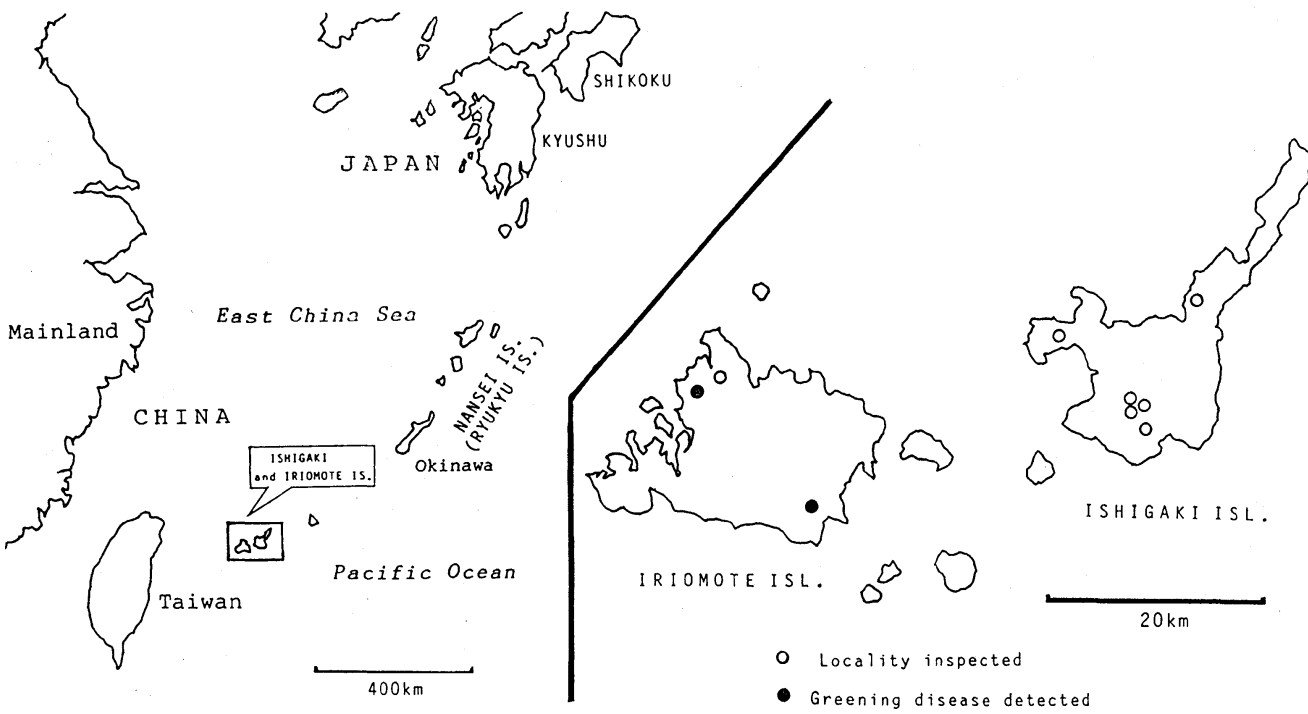

Fig. 1. The map showing the location of Ishigaki and Iriomote islands in southern Japan (left), and the places inspected in the both islands (right).

Quetol 812. The ultrathin sections were stained with uranyl acetate and aqueous lead acetate, and examined with a JEM-electron microscope. A bacterium-like organism, apparently identified to the greening pathogen was observed in the phloem sieve tubes of the infected Ponkan leaves (Fig. 3). The pleomorphic bodies found were spherical or oval, and surrounded by thick double membranes, and morphologically identical with greening pathogen observed in infected tissues in Taiwan ${ }^{8,9)}$.

Based on indexing and electron microscopy results, it is evident that citrus greening disease is present in the southern area of Japan. This is not unusual because the area is close to Taiwan where the citrus greening has been prevalent for many years. Furthermore, the insect vector, Diaphorina citri, is widely distributed in the Nansei islands.

Currently, there are few commercial citrus plantings in the islands, and citrus mostly exists as dooryard or roadside trees. Therefore, discovery of the greening disease in this area will not pose a commercial problem at this time. In this survey the affected citrus trees found were a local variety, Shiikuwasha, which are supposed to be seedling trees originating from seed in the islands. None of trees of other citrus species and varieties were found infected, so far.

Indexing was partially carried out in a greenhouse of Miyazaki Agricultural Experiment Station. We thank Mr. H. Hatano and Mr. Y. Kawano for their technical assistance. We also thank Dr. S.M. Garnsey, USDA Horticultural Research Laboratory, Orlando, Florida, USA for reading of the manuscript.

\section{和 文 摘 要}

宮川経邦・津野和宣 : 沖縄県西表島に抢けるカンキッグリーニング病の発生

沖縄県西表島のカンキッ（品種：シークワシャ）樹にカンキッグリーニング病の発生を確認した。罹病樹 は黄化, 小葉化, あるいは微量要素欠乏症など生理障害樹にみられる症状を表し, 固場観察だけでは同定で

8) Chen, M.H., Miyakawa, T. and Matsui, C. (1971). Phytopathology 61: 598. 9) Su, H.J. and Leu, S.C. (1972). Proc. Nat. Sci. Coun. (Taiwan) 5: 109-126. 

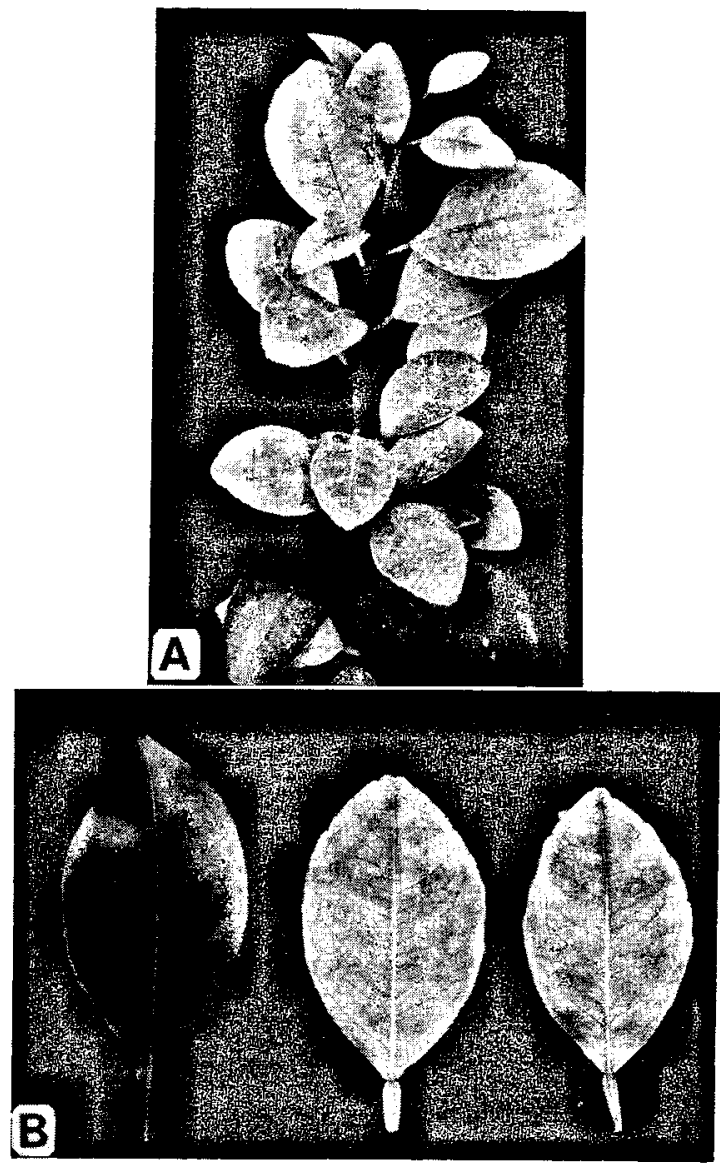

Fig. 2. A: A Ponkan seedling showing greening symptoms after bud-inoculation from a Shiikuwasha tree showing greening symptoms. B: Affected Ponkan leaves and uninoculated one (left).

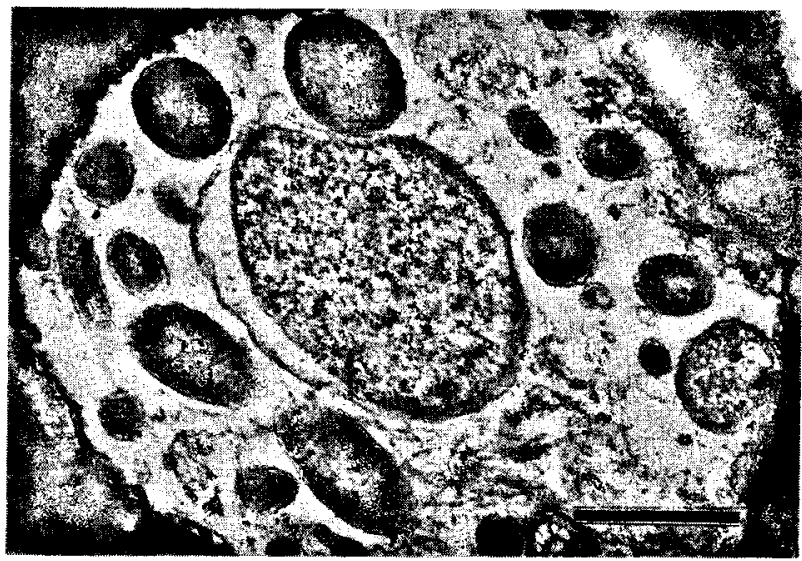

Fig. 3. Bacterium-like organism, spherical or oval, pleomorphic bodies, resembling greening pathogen in leaves of graft-inoculated Ponkan. (scale bar, $0.5 \mu \mathrm{m}$ ). 
きなかったが，ポンカン実生苗による検定からその接木伝染性と典型的なグリーニング病の病徴発現を確認 できた。超薄切片の電顕観察によって, 病徵を表した検定植物の罹病葉師管部組織の細胞内に, 不定形の, 厚い膜構造を有する細菌様微生物の存在を認めた。検定植物上の病徵, 病原体の形態, ならびにその病徵発 現温度域から, 中国, 台湾および東南アジア地に発生しているアジア系グリーニング病に属するものと考兄 られる。

(Received May 25, 1989) 